\title{
UJI ANTAGONIS Aspergillus sp. DAN Trichoderma spp. TERHADAP Fusarium sp., PENYEBAB PENYAKIT REBAH KECAMBAH PADA SENGON
}

\author{
Antagonistic Test of Trichoderma spp. and Aspergillus sp. Against \\ Fusarium sp., A Causal Agent of Damping-Off on Falcataria moluccana
}

\author{
Neo Endra Lelana, Illa anggraeni dan/and Nina Mindawati \\ Pusat Penelitian dan Pengembangan Peningkatan Produktivitas Hutan \\ Jl. Gunung Batu No. 5 Bogor 16118 Telp. 0251-8631238,Fax. 0251-7520005 \\ E-mail: neo_3L@yahoo.com
}

Naskah masuk : 10 Februari 2014; Naskah diterima : 6 Maret 2015

\begin{abstract}
Endophytic fungi is a group of fungi that can be developed as a biological control agent. Potency of endophytic fungi for agricultural crop has been discovered widely, but still rare for forest trees. The study was conducted to find out the antagonistic groups agains pathogen Fusarium sp. Fusarium is a casual agent of dumping-off on sengon tree. The highest average of inhibition after seven days incubation was shown by Trichoderma harzianum Bio1999, was 46.36\%, followed by isolates of Aspergillus sp. JTB 105, Trichoderma viride Bio19232, and Aspergillus sp. STB 107 were $41.72 \%, 31.13 \%$ and $28.48 \%$ respectively. Inhibition of Fusarium sp. occured through the mechanism of mutual inhibition. Based on the width of inhibition zone formed, isolate of Aspergillus sp. JTB105 of $2.25 \mathrm{~mm}$ showed the highest value, then followed by isolates of T. harzianum Bio1999, T. viride Bio19232 and Aspergillus sp. STB 107 which were $1.50 \mathrm{~mm}, 1.00 \mathrm{~mm}$ and $0.75 \mathrm{~mm}$ respectively.
\end{abstract}

Keywords: Antagonistic, biocontrol, endophytic fungi, Fusarium sp.

\begin{abstract}
ABSTRAK
Fungi endofit merupakan kelompok fungi yang dapat dikembangkan sebagai agen pengendali hayati. Studi mengenai potensi fungi endofit sudah banyak dilakukan untuk tanaman pertanian, namun masih sedikit untuk tanaman kehutanan. Penelitian ini dilakukan untuk melihat aktivitas antagonis dua isolat dari kelompok Aspergillus dan Trichoderma terhadap Fusarium sp. Peyebab penyakit rebah kecambah pada sengon. Penghambatan tertinggi pada hari ketujuh ditunjukkan oleh Trichoderma harzianum Bio1999, yaitu sebesar 46,36\% dan selanjutnya berturut-turut diikuti isolat Aspergillus sp. JTB 105, T. viride Bio19232, dan Aspergillus sp. STB 107 masing-masing sebesar 41,72\%; 31,13\% dan 28,48\%. Penghambatan terhadap Fusarium sp. terjadi melalui mekanisme mutual inhibisi. Berdasarkan panjang zona inhibisi yang terbentuk, isolat Aspergillus sp. JTB105 menunjukkan hasil yang tertinggi, yaitu sebesar $2,25 \mathrm{~mm}$ dan selanjutnya berturut-turut diikuti isolat T. harzianum Bio1999, T. viride Bio19232 dan Aspergillus sp. STB 107 masing-masing sebesar 1,50 $\mathrm{mm} ; 1,00 \mathrm{~mm}$ dan 0,75 $\mathrm{mm}$.
\end{abstract}

Kata kunci: Antagonis, biokontrol, fungi endofit, Fusarium sp.

\section{PENDAHULUAN}

\section{A. Latar Belakang}

Fusarium sp. merupakan fungi penghuni tanah (soil borne pathogen) yang menyebabkan penyakit rebah kecambah (damping-off) dan busuk akar terutama pada bibit. Fungi ini bersifat parasit fakultatif, dapat hidup sebagai saprofit di atas permukaan tanah, dan berubah menjadi parasit apabila ada tanaman inang dan kondisi lingkungan yang baik untuk pertumbuhan patogen. Selain pada sengon, jenis patogen tersebut dilaporkan menyerang pada beberapa tanaman lain, diantaranya gmelina, akasia, ekaliptus dan jati (Anggraeni et al., 2010).

Pengendalian dengan memanfaatkan agen hayati merupakan bagian dari pengelolaan hama dan penyakit secara terpadu telah disarankan sebagai solusi jangka panjang yang paling baik (Bateman, 2002). Salah satu agen hayati yang potensial untuk dikembangkan ialah fungi. Berbagai jenis fungi d-pat dikembangkan sebagai agen pengendali hayati, salah satunya fungi endofit. Fungi endofit merupakan kelompok fungi yang dapat berasosiasi dengan berbagai jaringan dan organ tanaman, infeksi yang terjadi 
tidak terlihat dan tanaman tidak menunjukkan gejala terinfeksi serta tidak menyebabkan pertumbuhan tanaman terganggu (Stone et al., 2000; Saikkonen et al.,1998). Fungi endofit dapat memberikan keuntungan bagi tanaman dengan membantu pertumbuhan tanaman inang (Dai et al., 2008), melindungi tanaman dari hama dan penyakit (Mejia et al., 2008; Vega et al., 2008), dan meningkatkan resistensi tanaman dari berbagai jenis cekaman (Lewis, 2004).

Berbagai penelitian menunjukkan fungi endofit berpotensi sebagai agen hayati untuk mengendalikan berbagai jenis patogen, diantaranya terhadap Colletotrichum falcatum (Prince et al., 2011), Pythium spp. (Jeyaseelan et al., 2012; Gomathy and Ambikapathy, 2011; Mishra et al., 2010), Moniliophthora spp. (Meija et al., 2008), dan Phytophthora spp. (Meija et al., 2008). Di antara fungi endofit yang saat ini paling banyak dipelajari dan dikembangkan sebagai agen hayati ialah dari kelompok Trichoderma (Harman et al., 2004). Kelompok fungi ini bahkan sudah banyak diproduksi secara ko-mersial. Namun demikian sebagian besar masih bersifat spesifik untuk jenis patogen tertentu dan kondisi lingkungan tertentu. Untuk itu upaya pe-ngembangan fungi endofit yang efektif untuk kondisi lingkungan dan jenis patogen yang lebih luas perlu terus dilakukan.

Pada penelitian ini dua isolat fungi endofit dari kelompok Aspergillus dan fungi antagonis dari kelompok Trichoderma diuji aktivitas antagonisnya terhadap patogen penyebab penyakit rebah kecambah (damping-off) pada tanaman sengon, yaitu Fusarium sp.

\section{METODOLOGI}

\section{A. Isolat Fungi}

Isolat fungi yang digunakan dalam penelitian ini yaitu T. harzianum Bio1999 dan T. viride Bio19232 yang dikoleksi dari South East Asia Center for Tropical Biology (SEAMEO BIOTROP), dan isolat Aspergillus sp. STB 107 yang diisolasi dari tanaman sengon dan Aspergillus sp. JTB 105 diisolasi dari tanaman jabon.

\section{B. Uji Antagonistik}

Aktivitas antagonistik fungi terhadap patogen dilakukan secara in vitro dengan metode dual plate assay (Mejia et al., 2008; Sharfuddin and Mohanka, 2012). Koloni fungi dan patogen berdiameter $3 \mathrm{~mm}$ diinokulasikan pada media PDA $2 \%$ dalam satu petridisk yang berdiameter 9 $\mathrm{cm}$ dengan jarak $4 \mathrm{~cm}$. Fungi diinokulasi dalam media dua hari setelah inokulasi patogen. Petridisk selanjutnya diinkubasi di ruang gelap pada suhu ruang. Evaluasi dilakukan dengan menghitung persentase penghambatan fungi terhadap Fusarium sp. yang mulai dilakukan setelah satu hari inokulasi fungi sampai dengan hari ketujuh. Persentase penghambatan dihitung dengan rumus berikut :

$$
\begin{aligned}
& \text { Dimana: } P=\frac{r 1-r 2}{\text { penghambatan }} \times 100 \text { fungi terhadap } \\
& \mathrm{P}=\text { Persentase } \\
& \text { patogen }
\end{aligned}
$$

\section{Rancangan Percobaan}

Penelitian dilakukan menggunakan rancangan acak lengkap (RAL) yang terdiri empat taraf yaitu T. harzianum Bio1999, T. viride Bio19232, Aspergillus sp. STB 107 dan Aspergillus sp. JTB 105. Setiap perlakuan diulang empat kali. Parameter yang diamati ialah persentase penghambatan isolat uji terhadap patogen dan lebar zona inhibisi yang diukur pada akhir pe-ngujian, yaitu hari ketujuh. Zona inhibisi me-rupakan daerah yang tidak terkolonisasi diantara ujung miselium isolat uji dan patogen yang berhadapan.

Model linear aditif dari rancangan ini sebagai berikut:

$$
\mathrm{Yij}=\mu+\alpha_{\mathrm{i}}+\varepsilon_{\mathrm{ij}}
$$

Dimana: $\quad$ Yij $=$ nilai pengamatan pada perlakuan ke-i ulangan ke-j; $\mu=$ rataan umum; $\alpha_{\mathrm{i}}=$ pengaruh perlakuan ke-i; dan $\varepsilon_{\mathrm{ij}}=$ pengaruh acak pad perlakuan ke-i ulangan ke-j.

\section{Analisis Data}

Pengamatan uji penghambatan dilakukan setiap hari sampai hari ketujuh, sementara untuk antibiosis dilakukan pada akhir pengujian (hari ketujuh). Data yang diperoleh selanjutnya dianalisis sidik ragam dengan program statistik IBM SPSS Statistics versi 20. Selanjutnya jika terjadi pengaruh yang signifikan maka dilakukan uji perbandingan rataan dengan uji Tukey pada taraf nyata $5 \%$.

\section{HASIL DAN PEMBAHASAN}

\section{A. Hasil}

Uji antagonis empat isolat fungi endofit yaitu 
T. harzianum Bio1999, T. Viride Bio19232, Aspergillus sp. STB 107 dan Aspergillus sp. JTB 105 dilakukan terhadap patogen Fusarium sp. Rata-rata penghambatan fungi endofit selama tujuh hari pengujian terhadap Fusarium sp. disajikan pada Gambar 1. Rata-rata persentase penghambatan terlihat meningkat setiap hari sampai pengamatan hari ke-tujuh, namun demikian penghambatan yang ditunjukkan oleh isolat T. viride Bio19232 dan Aspergillus STB 107 setelah hari keempat cenderung menu-run dan meningkat lagi setelah hari ketujuh. Pada hari ketujuh, rata-rata penghambatan tertinggi ditunjukkan oleh T. harzianum Bio1999, yaitu sebesar $46,36 \%$ dan selanjutnya berturut-turut diikuti isolat Aspergillus sp. JTB 105, T. viride Bio19232, dan Aspergillus sp. STB 107 masingmasing sebesar $41,72 \% ; 31,13 \%$ dan $28,48 \%$. Walaupun isolat T. harzianum Bio1999 tertinggi namun secara statistik nilai ini tidak berbeda nyata dengan isolat Aspergillus sp. JTB 105.

Penghambatan isolat fungi yang diuji terhadap Fusarium sp. merupakan penghambatan dengan mekanisme inhibisi mutual. Penghambatan dengan mekansime ini dicirikan oleh adanya zona inhibisi yang terbentuk (Gambar 2). Sementara itu untuk mekanisme parasitisme sampai hari kedelapan pengamatan belum terdeteksi. Berdasarkan grafik yang disajikan pada Gambar 3, pembentukan zona inhibisi tertinggi ditunjukkan oleh Aspergilllus sp. JTB 105, yaitu sebesar $2,25 \mathrm{~mm}$ dan selanjutnya berturut-turut diikuti isolat $T$. harzianum Bio1999, T. viride Bio19232 dan Aspergillus sp. STB 107 masing-masing sebesar $1,50 \mathrm{~mm} ; 1,00 \mathrm{~mm}$ dan $0,75 \mathrm{~mm}$. Namun demikian nilai ini tidak berbeda secara statistik.

\section{B. Pembahasan}

Trichoderma spp. merupakan jenis fungi yang aktivitas antagonisnya telah banyak dipelajari, sedangkan Aspergillus spp. masih sedikit. Pada



Gambar(Figure) 1.Rata-rata persentase penghambatan fungi endofit terhadap patogen Fusarium sp. (Average of percentage of fungal endophytes inhibition against Fusarium sp.)

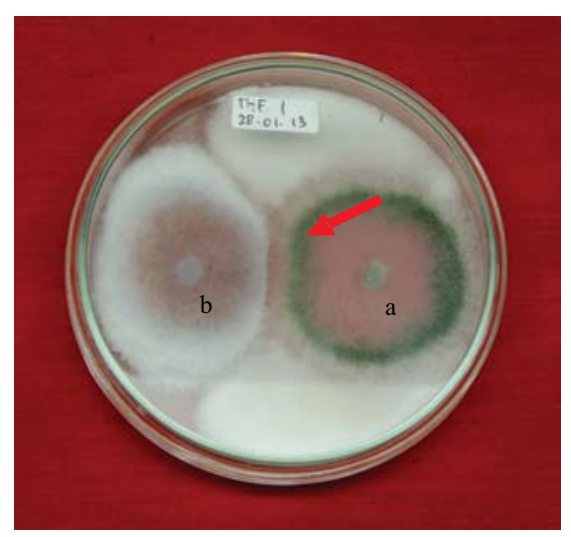

Gambar(Figure)2.Zona inhibisi yang terbentuk (tanda panah) pada uji antagonis fungi endofit $T$. harzianum Bio1999 (a) terhadap Fusarium sp. (b) pada hari ketujuh pengamatan (Zone of inhibition formed on fungal endophytes antagonistic test of T. harzianum Bio1999 against Fusarium sp. after 7 days incubation) 


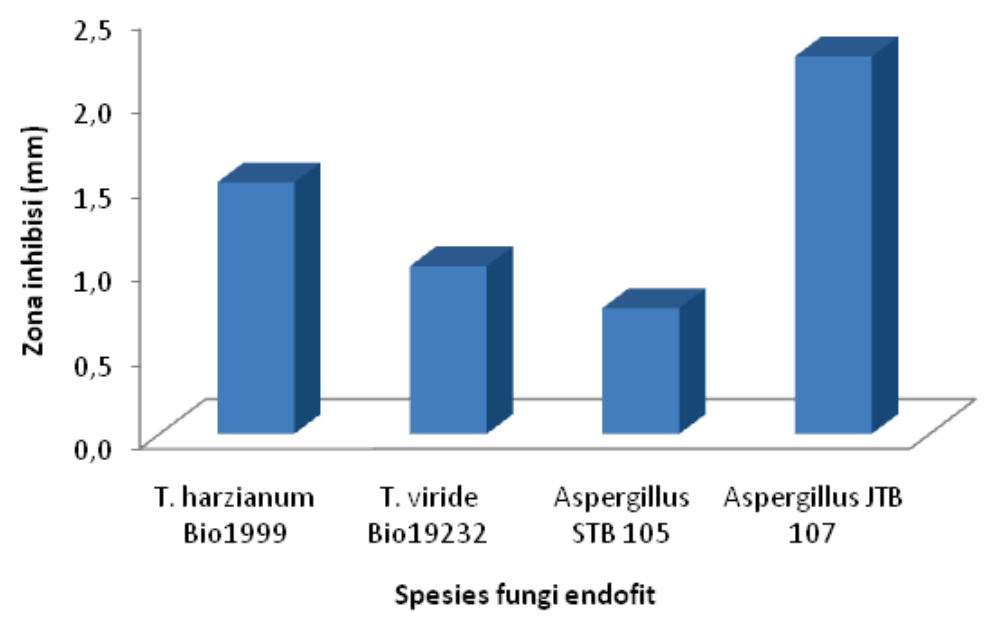

Gambar(Figure) 3. Lebar zona inhibisi yang terbentuk pada uji antagonis fungi endofit terhadap Fusarium sp. pada hari ke-7 pengamatan (The width of inhibition zone formed on fungal endophytes antagonistic test against Fusarium sp. after 7 days incubation).

pengujian yang dilakukan Sharfuddin and Mohanka (2012) menunjukkan isolat $T$. harzianum Th-5 mampu menghambat pertumbuhan $F$. oxysporum f.sp. lentis sebesar $82,8 \%$ dan $T$. viride $T v-2$ sebesar $79,2 \%$. Sementara Rajeswari \& Kannabiran (2011) melaporkan isolat $T$. viride mampu menghambat pertumbuhan $F$. oxysporum sebesar $89,4 \%$ dan $T$. harzianum sebesar $83,15 \%$ sedangkan Lone et al. (2012) melaporkan bahwa T. harzianum hanya menghambat pertumbuhan $F$. oxysporum sebesar 25\%. Dibandingkan dengan penelitian sebelumnya, isolat uji yang digunakan terlihat mempunyai aktivitas lebih rendah dibandingkan penelitian Sharfuddin \& Mohanka (2012) maupun Rajeswari \& Kannabiran (2011), namun lebih tinggi dibandingkan penelitian Lone et al. (2012). Perbandingan secara langsung hasil tersebut memang sulit dilakukan karena banyaknya faktor yang mempengaruhi, seperti komposisi media, isolat patogen dan metode pengujian yang digunakan.

Mekanisme penghambatan fungi endofit terhadap patogen terjadi melalui beberapa mekanisme, diantaranya antibiosis, yaitu penghambatan pertumbuhan ditandai dengan terbentuknya zona inhibisi; kompetisi terhadap substrat, yaitu pertum-buhan yang lebih cepat terhadap lainnya; dan mikoparasitisme, yaitu parasitisme langsung pada hifa patogen (Mejia et al.,
2008). Berdasarkan mekanisme tersebut, penghambatan isolat fungi yang diuji terhadap Fusarium sp. merupakan penghambatan dengan mekanisme inhibisi mutual. Mekanisme inhibisi ini biasanya akan diikuti oleh parasitisasi terhadap patogen, namun demikian tidak semua agen hayati mampu mencapai tingkat para-sitisasi, seperti interaksi antara Trichoderma dan Fusarium. Menurut Sharma (2011), interaksi antara Trichoderma dan Fusarium dimulai dengan mekansime antibiosis dan pada akhirnya Trichoderma akan mampu memparasit Fusarium. Namun demikian kondisi ini sangat tergantung isolat kedua fungi tersebut, sehingga pada akhirnya tidak semua Trichoderma mampu mencapai tingkatan untuk memparasit Fusarium. Pada hari kedelapan uji, isolat uji Trichoderma spp. dan Aspergillus spp. terlihat belum mampu memparasit Fusarium sp. Ada dua kemung-kinan yang dapat terjadi yaitu pertama karena ketidakmampuaan isolat uji untuk memparasit Fusa-rium sp. atau yang kedua perlu waktu lebih dari delapan hari bagi isolat uji untuk memparasit Fusarium sp.

Pembentukan zona inhibisi diduga berkaitan dengan metabolit sekunder maupun senyawa antibiosis yang disekresi oleh fungi endofit. Senyawa antibiosis disekresikan oleh fungi Aspergillus dan Trichoderma maupun oleh Fusarium. Beberapa studi menunjukkan bahwa Trichoderma sp. menghasilkan berbagai metabolit sekunder dan senyawa antibiotik, seperti peptaibol (Shakeri \& Foster, 2007), alkyl pyrones (Hasan et al., 2007), isonitriles (Fujiwara 
et al., 1982). Sementara pada Aspergillus sp. diantaranya tensyuic acid (Hasegawa, et al., 2007); cyclopentenedione, diketopiperazines, lactone, benzophenone, terpene, anthraquinone, diphenyl ethers, dan alkaloid (Xue et al., 2012).

Kelebihan Trichoderma sebagai agen hayati adalah kemampuannya dalam mengembangkan mekanisme antagonisme yang sangat efektif untuk bertahan dan mengkolonisasi lingkungan yang kompetetif di rizosfer, filosfer dan spermosfer. Sebagian besar sistem antifungi terdiri atas gengen yang menyandikan sejumlah enzim pelisis, seperti endokitinase, $\mathrm{N}$-asetil- $\beta$-glukosaminidase, kitin 1,4- $\beta$-kitobiosidase, protease, $\beta$ 1,3-gluko-sidase, $\beta$-1,6-glukosidase, lipase, xilanase, manna-nase, pektinase, pectin liase, amylase, fosfolipase, RNase dan DNase. Namun demikian yang lebih berperan dalam aplikasi biokontrolnya ialah enzim kitinase dan glukanase yang secara efisien mendegradasi dinding sel fungi patogen dan tidak terdapat pada jaringan tanaman (Monte, 2001; Lorito, 1998).

\section{KESIMPULAN DAN SARAN}

Isolat T. harzianum Bio1999 dan Aspergillus sp. JTB 105 diindikasikan mempunyai kemampuan lebih baik dibandingkan isolat $T$. viride Bio19232, dan Aspergillus sp. STB 107 dalam menghambat Fusarium sp. melalui mekanisme inhibisi.

\section{DAFTAR PUSTAKA}

Anggraeni, I., Lelana N.E. , \& Darwiati W. (2010). Pengelolaan hama dan penyakit hutan tanaman. Sintesis Hasil-hasil Penelitian Lingkup Pusat Penelitian dan Pengembangan Hutan Tanaman Tahun 2003-2009.

Bateman, R. (2002). Best-bet solutions for cocoa diseases. Gro-Cocoa Newsletter 1: 4-5.

Dai C.C., Yu, B.Y. Li, \& X. (2008). Screening of endophytic fungi that promote the growth of Euphorbia pekinensis. Afr. J. Biotechnol. 7: 3505-3509.

Fujiwara, A., Okuda, T. Masuda, S. Shiomi, Y. Miyamoto, C. Sekine, Y. Tazoe, M. \& Fujiwara M. (1982). Fermentation, isolation and cha-racterization of isonitrile antibiotics. Agric. Biol. Chem. 46:1803-1809.
Gomathi, S. \& Ambikapathy, V. (2011). Antago-nistic activity of fungi against Pythium debaryanum (Hesse) isolated from Chilli field soil. $A d v$. App. Sci. Res. 2 (4): 291-297.

Harman, G.E, Howell, C.R Viterbo, A. Chet, I. Loritto, M. (2004). Trichoderma species opportu-nistic, avirulent plant symbionts. Nat. Rev. Microbiol. 2: 43-56.

Hasan, A.E, Walker, F. Schöne J. \& Buchenauer, H. (2007). Antagonistic effect of 6-pentylalphapyrone produced by Trichoderma harzianum toward Fusarium moniliforme. J. Plant Dis. Protect. 114 (2): 62-68.

Hasegawa, Y., Fukuda, T. Hagimori, K. Tomoda, H. \& Omura, S. (2007). Tensyuic acids, new antibiotics produced by Aspergillus niger FKI2342. Chem. Pharm. Bull. 55 (9) : 1338-1341.

Jeyaseelan, E.C., Tharmila, S. \& Niranjan, K. (2012). Antagonistic activity of Trichoderma spp. and Bacillus spp. against Pythium aphanidermatum isolated from tomato damping off. Arch. App. Sci. Res. 4 (4):1623-1627.

Lewis, G.C. (2004). Effects of biotic and abiotic stress on the growth of three genotypes of Lolium perenne with and without infection by the fungal endophyte Neotyphodium lolii. Ann. Appl. Biol. 144: 53-63.

Lone, M.A., Wani, M.R. Sheikh, S.A. Sahay, S. Dar M.S.. 2012. Antagonistic Potentiality of Trichoderma harzianum Against Cladosporium spherospermum, Aspergillus niger and Fusarium oxysporum. J. Biol. Agr. Healthcare 2(8): 72-76.

Lorito, M. (1998). Chitinolytic enzymes and their genes. In CP Kubicek and GE Harman eds. Trichoderma and Gliocladium Vol 2. Lon-don: Taylor and Francis

Mejia, L.C., Rojas, E.I. Maynard, Z. Van Bael, S. Arnold, A. E. Hebbar, P. Samuels, G.J. Robbins, N. Herre, E.A. (2008). Endophytic fungi as biocontrol agents of Theobroma cacao patho-gens. Biol. Control 46 (4): 14.

Mishra, V.K. 2010. In vitro antagonism of Trichoderma species against Pythium aphanidermatum. J. Phytol. 2(9): 28-35.

Monte, E. 2001. Understanding Trichoderma: between bio-technology and microbial ecology. Int. Microbial 4: 1-4.

Prince, L., Raja, A. \& Prabakaran, P. (2011). Antagonistic potentiality of some soil mycoflora against Colletotrichum falcatum. World J.Sci. and Technol. 1(4): 39-42. 
Rajeswari, P. \&Kannabiran, B. (2011). In vitro effects of antagonistic microorganisms on Fusarium oxysporum [Schlecht. Emend. Synd \& Hans] infecting Arachis hypogaea L. J. Phytol. 3(3): 83-85.

Saikkonen, K., Faeth, S.H Helander, M. \& Sullivan, T. J. (1998). Fungal Edophytes: A conti-nuum of interactions with host plants. Ann. Rev. of Ecol. Systemat. 29:319-343.

Shakeri, J \& H.A. Foster. (2007). Proteolytic activity and antibiotic production by Trichoderma harzianum in relation to pathogenicity to insects. Enzyme and Microb. Technol. 40 (4): 961-968.

Sharfuddin, C. \& Mohanka R. (2012). In vitro antagonism of indigenous Trichoderma isolates against phytopathogen causing wilt of lentil. Int. J. Life Sci. and Pharma Res. 2 (3): 195202.
Sharma, P. (2011). Complexity of TrichodermaFusa-rium interaction and manifestation of biologi-cal control. Australian J of Crop Sci. 5(8): 1027-1038.

Stone J.K., Bacon, C.W. White Jr, J.F. (2000). An overview of endophytic microbes: endophytism defined. In: Bacon, C.W., White, J.F., Jr. (Eds.). Microbial Endophytes. New York, Marcel Dekker, pp. 3-30.

Vega F.E. Posada, F. Aime, M.C. Pava-Ripoll, M. Infante, F., Rehner, S.A. (2008). Entomopathogenic fungal endophytes. Biol. Control 46: 72-82.

Xue, H., Lu, C. Liang, L. Shen, Y. (2012). Secondary Metabolites of Aspergillus sp. CM9a, an Endophytic Fungus of Cephalotaxus mannii. Rec. Nat. Prod. 6 (1): 28-34. 